\title{
Analisis Semiotik Pada Pelaporan Corporate Social Responsibility (CSR) Saat Pandemi Covid-19 Di Pertamina TBBM Baubau
}

\section{Endang Tri Pratiwi ${ }^{1 *}$, Ekapratna Paradita ${ }^{1}$, Wa Ode Harbiyah Syuhadah ${ }^{1}$, Ivon} Septya Ramadani ${ }^{1}$, Siti Nurhaliza ${ }^{1}$

${ }^{1}$ Fakultas Ekonomi, Universitas Muhammadiyah Buton, Indonesia

*Korespondensi: endangtripratiwi12@gmail.com

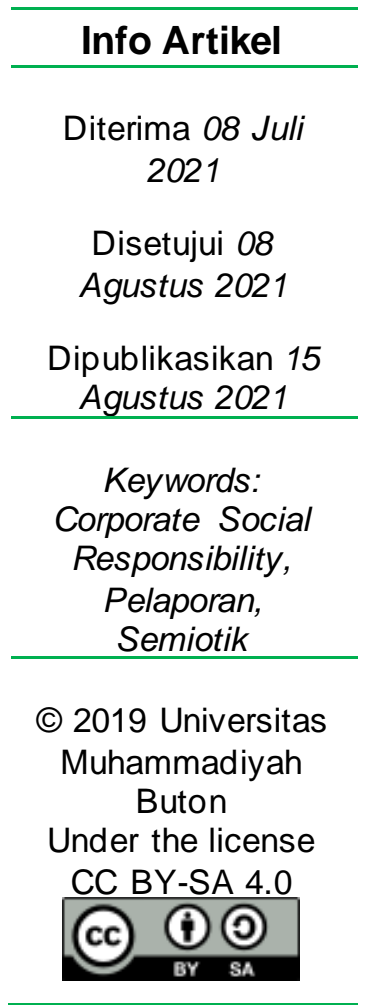

\section{Abstrak}

Upaya Pemerintah Indonesia dalam menangani wabah Covid-19 membutuhkan dukungan dari pihak swasta/lembaga lainnya dengan kapasitas pendanaan memadai. Salah satu BUMN yang berkontribusi aktif dalam penanganan wabah tersebut adalah PT. Pertamina (Persero). Penelitian ini bertujuan untuk mengetahui analisis semiotik pelaporan Corporate Social Responsibility (CSR) saat pandemi Covid-19 pada Pertamina TBBM Baubau. Populasi dalam penelitian ini adalah seluruh pelaporan CSR Pertamina TBBM Baubau, sedangkan yang menjadi sampel adalah pelaporan CSR Pertamina TBBM Baubau saat pandemi Covid-19 tahun 2020. Metode pengumpulan data melalui wawancara, dokumentasi, dan studi kepustakaan. Adapun analisis data yang digunakan adalah analisis semiotik melalui paradigma deskriptif analitik terhadap pemaknaan simbol, kata dan kalimat dalam laporan CSR Pertamina TBBM Baubau. Hasil penelitian menunjukkan terdapat empat program CSR yang dialihkan secara penuh terhadap upaya penanganan Covid-19 di Kota Baubau tahun 2020. Kondisi ini merupakan sinergi antara Pemerintah Kota Baubau dan manager perusahaan atas upaya penanganan Covid-19 melalui penyaluran dana CSR.

\section{Abstract}

The Indonesian Government's efforts in dealing with the Covid-19 outbreak require support from private sector/other institutions with adequate funding capacity. One of the BUMNs that actively contributed to the handling of the outbreak was PT. Pertamina. This study aims to determine the semiotic analysis of Corporate Social Responsibility (CSR) reporting during the Covid-19 pandemic at Pertamina TBBM Baubau. The population were all of Pertamina TBBM Baubau CSR reports, while the sample was Pertamina TBBM Baubau CSR reporting during the Covid-19 pandemic in 2020. Data collection methods were through interviews, documentation, and literature study. The data analysis used is semiotic analysis through a descriptive analytic paradigm in accordance with the meaning of symbols, words and sentences in the CSR reporting of Pertamina TBBM Baubau. The results showed that there were four CSR programs that were fully transferred to the handling of Covid-19 at Baubau City in 2020. This condition is a synergy between the Government and managers for efforts to handle Covid-19 through the distribution of CSR funds. 


\section{Pendahuluan}

Perekonomian global ikut terkena dampak dari merosotnya perekonomian Tiongkok karena pandemi Covid-19. Beberapa lembaga riset kredibel dunia memprediksi dampak buruk penyebaran wabah ini terhadap ekonomi global. Untuk Indonesia sendiri, Menteri Keuangan, Sri Mulyani Indrawati memprediksi pertumbuhan ekonomi dalam skenario terburuk bisa mencapai minus $0,4 \%$. Diantara bentuk upaya yang diserukan dan dilakukan oleh dunia untuk mengurangi penyebaran wabah ini adalah dengan social atau physical distancing. Namun sayangnya, gerakan ini berpengaruh pada penurunan aktivitas ekonomi secara keseluruhan.

Kondisi ini memaksa kontribusi pemerintah khususnya Pemerintah Indonesia turut andil dalam menstabilkan perekonomian masyarakat. Pemerintah harus bertindak cepat dan tepat dalam upaya pemulihan ekonomi. Salah satu bentuk upaya tersebut adalah peluncuran dana bantuan langsung tunai (BLT) kepada masyarakat yang terkena dampak dan perampingan anggaran seluruh instansi/lembaga secara efektif, efisien dan ekonomis yang berfokus pada penanganan wabah COVID-19. Namun, upaya pemerintah tersebut dipandang perlu mendapat dukungan dari pihak swasta/lembaga lainnya yang memiliki kapasitas pendanaan memadai dalam penanganan wabah ini mengingat wilayah Indonesia yang cukup luas dan mayoritas masyarakatnya terkena dampak.

Dukungan dari pihak swasta/lembaga lainnya seperti BUMN mulai terdengar gaungnya sejak Menteri Badan Usaha Milik Negara (BUMN) Erick Thohir menginstruksikan kepada seluruh dana tanggung jawab sosial perusahaan (corporate social responsibility/CSR) BUMN agar dititikberatkan untuk membantu penanganan COVID-19 https://mediaindonesia.com/read/detail/298036-dana-csrbumn-untuk-bantu-penanganan-covid-19.

Bagian tak terpisahkan dari akuntansi, CSR reporting bukan merupakan praktik dengan sifat statis dan pengabaian terhadap faktor dinamika sosial (Hines, 1988). Akuntansi merupakan praktik yang berkembang secara terus-menerus dan terbentuk melalui social interaction antara manusia dengan alam sekitarnya (Anis Chariri, 2008). Jika ditinjau pada perspektif konstruksi sosial, praktik terhadap financial reporting bukan hanya menginformasikan pernyataan berbentuk kuantitatif, namun menginformasikan pula pernyatan lain berupa narrative text, image, tabel, dan chart/grafik (Chariri \& Nugroho, 2009). Salah satu bentuk informasi tersebut adalah pelaporan aktivitas CSR dalam sustainability reporting. Beragam motif perusahaan dalam pengungkapan CSR telah diteliti sebelumnya seperti untuk menarik investor, memenuhi ketaatan terhadap peraturan, peningkatan competitive advantages, pemenuhan kontrak pinjaman dan harapan masyarakat, serta proses legitimasi tindakan korporasi (Basalamah \& Jermias, 2005).

Salah satu BUMN yang aktif dalam melaksanakan CSR saat pandemi Covid 19 adalah PT. Pertamina (Persero) khususnya PT Pertamina (Persero) TBBM Baubau. Bantuan PT Pertamina dalam bentuk CSR sejak awal mewabahnya Covid-19 sudah banyak diserahkan khususnya untuk tenaga medis yang menjadi barisan terdepan dalam upaya penanganan warga yang menjadi korban virus ini. Berdasarkan fenomena tersebut, penelitian ini akan mengkaji "Analisis Semiotik 
Pelaporan Corporate Social Responsibility (CSR) saat Pandemi Covid-19 pada PT. Pertamina (Persero) TBBM Baubau.

\section{Metode Penelitian}

Penelitian ini mengamati pelaksanaan CSR yang dilakukan oleh Pertamina TBBM Baubau selama pandemi Covid-19 pada tahun 2020. Lokasi penelitian beralamat di Jalan Gajah Mada Km. 08, Sulaa, Kecamatan Betoambari Kota Baubau Sulawesi Tenggara. Populasi penelitian ini adalah seluruh pelaporan CSR Pertamina TBBM Baubau. Sedangkan sampel adalah pelaporan CSR Pertamina TBBM Baubau saat pandemi Covid-19 tahun 2020.

Metode pengumpulan data dalam penelitian ini dilakukan beberapa tahap, yakni 1) Pengumpulan data sekunder, tahap ini bertujuan untuk memperoleh data melalui interview dan dokumentasi dari berbagai media seperti media perusahaan, internet dan publikasi; dan 2) Studi kepustakaan, bertujuan untuk menambah khasanah teori dan bahan analisis. Tahap ini dilakukan dengan mengumpulkan dan mempelajari buku teks, laporan, artikel, dan jurnal ilmiah yang terkait dengan penelitian ini.

Analisis data yang dilakukan adalah analisis semiotik terhadap keseluruhan naratif teks yang dijabarkan dalam sustainability report. Semiotik atau dalam istilahnya dikenal dengan semiologi, hakikatnya adalah ilmu yang ingin mengetahui keberadaan kemanusiaan (humanity) proses pemaknaan hal-hal (things) (Chariri \& Nugroho, 2009). Hal ini bermaksud bahwa segala fenomena kehidupan dapat divisualisasikan dalam bentuk tanda, artinya kita dapat memaknai segala sesu atu . Tanda dapat dideskripsikan sebagai kolaborasi antara pola (yang dideskripsikan oleh pikiran seseorang) dan makna atau konten (pemahaman manusia sebagai user).

Analisis semiotik terhadap keseluruhan teks narasi merupakan suatu analisis yang menjadikan struktur kalimat sebagai pedoman dalam proses eksplanasi suatu teks narasi. Komponen data yang menjadi peran sebagai obyek analisis adalah teks. Penggolongan teks terdiri atas dua subgolongan, yakni (a) teks yang terwakilkan dari unsur experience/pengalaman, dianalisis dengan teknik elisitasi secara berurutan yaitu pengidentifikasian keseluruhan unsur teks yang menjadi partisi atas suatu kebudayaan dan proses pengkajian hubungan antarunsur tersebut) atau analisis teks dengan berlandaskan analisis kata atau teks sebagai sistem tanda, dan (b) teks sebagai objek analisis dengan melakukan analisis terhadap percakapan, narasi, parole, atau struktur gramatikal (Hoed, 2011). Penelitian ini menggunakan data teks yang termasuk sub golongan (a). Rangkaian proses analisis data berorientasi pada paradigma deskriptif analitik sesuai dengan pemaknaan simbol, kata dan kalimat yang ditemui dalam laporan CSR Pertamina TBBM Baubau.

\section{Hasil}

\subsection{Sejarah Pertamina TBBM Baubau}

Pertamina TBBM Baubau atau FuelTerminal Baubau adalah salah satu Fuel Terminal Pertamina yang berada di bawah Marketing Operation Region VII yang berlokasi di Kota Baubau, Provinsi Sulawesi Tenggara. Fuel Terminal Baubau terdiri atas dua lokasi, yaitu: 1) Lokasi Baru dengan luas 20,6 Ha yang beralamat di JI. Dayanu Ikhsanuddin, Km.8, Kel. Sulaa, Kec. Betoambari, dibangun sejak 
tahun 2008 dan mulai beroperasi sejak bulan Februari 2012; dan 2) Lokasi lama dengan luas 3,4 Ha yang beralamat di Jl. Betoambari, Km.4, Kel. Katobengke, Kec. Betoambari dan mulai beroperasi sejak tahun 1980.

Fuel Terminal Baubau di lokasi baru, dalam pengoperasiannya sudah menerapkan Terminal Automation System (TAS) dengan tugas pokok adalah menyediakan dan melayani kebutuhan BBM Premium, Solar, Biosolar, Pertamax dan Pertalite untuk disalurkan menggunakan mobil tangka/multi-moda \& tanker dengan wilayah operasi untuk local sales meliputi 5 wilayah yaitu: Kota Baubau, Kab. Buton, Kab. Buton Utara, Kab. Buton Selatan, Kab. Wakatobi dan Kab. Muna untuk produk kerosene.

\section{Aktivitas CSR oleh Pertamina TBBM Baubau Selama Pandemi Covid-19}

Beberapa pihak mengemukakan pendapat bahwa perusahaan adalah penyebab rusaknya lingkungan, tereksploitasinya sumber daya alam, dan aktivitas utamanya hanya profit dan profit semata (Narsa \& Irwanto, 2014). Nyatanya, perusahaan adalah aktor utama yang dapat mendukung terciptanya pertu mbu $\mathrm{h}$ an ekonomi di suatu kota, kabupaten, provinsi bahkan negara. Pertumbuhan ekonomi tersebut tentunya harus didukung dengan peningkatan sosial dan lingkungan perusahaan. Pelaksanaan CSR dengan berlandaskan Profit, People, and Planet (3P) masih menimbulkan ketidakseimbangan bagi masyarakat dan lingkungan, sehingga memunculkan kesan tidak bersungguh-sungguh (Pertiwi \& Ludigdo, 2013).

Pertamina terus berkomitmen untuk senantiasa memprioritaskan keseimbangan dan kelestarian alam, lingkungan dan masyarakat. Pertamina mengelola kegiatan Tanggung Jawab Sosial Lingkungan (TJSL), salah satu programnya mencakup program Corporate Social Responsibility (CSR). Perwujudan komitmen Pertamina dalam melaksanakan TJSL meliputi kegiatan CSR pada bidang pendidikan, kesehatan, lingkungan, infrastruktur, pemberdayaa $n$ masyarakat, manajemen bencana, maupun bantuan khusus. Selama pandemic Covid-19 terjadi di Indonesia, Pertamina selaku perusahaan energi nasional (BUMN) turut berkontribusi dalam pencegahan dan penanggulangan Covid-19, salah satunya Pertamina TBBM Baubau.

Hasil wawancara kami pada hari rabu tanggal 30 Desember 2020 pukul 10.35 WITA kepada Bapak Adi Rachman, selaku manager Pertamina TBBM Baubau tentang aktivitas CSR selama pandemic Covid-19, menyampaikan bahwa:

"Sejatinya tidak ada aktivitas CSR yang dikhususkan "untuk Covid-19" di tahun 2020 ini, karena seluruh perencanaan program dilakukan pada tahun sebelumnya. Jadi, perencanaan program CSR untuk tahun 2020 ini awalnya berupa kegiatan penanaman terumbu karang, pembuatan outlet tenun masyarakat di Kelurahan Sulaa, kegiatan pendampingan marketing produk tenun dan kegiatan CSR lainnya yang telah disahkan oleh Marketing Operation region (MOR) VII Sulawesi atas usulan Pertamina TBBM Baubau. Namun, Indonesia terkena dampak pandemic Covid-19 di tahun 2020 sehingga beberapa kegiatan CSR tersebut diubah peruntukkannya menjadi kegiatan CSR dalam pencegahan dan penanggulangan Covid-19".

Berdasarkan petikan wawancara diatas, aktivitas CSR Pertamina TBBM Baubau tahun 2020 terdiri atas kegiatan penanaman terumbu karang, pembuatan outlet tenun masyarakat di Kelurahan Sulaa, dan kegiatan pendampingan 
marketing produk tenun adalah tiga bentuk aktivitas CSR Pertamina TBBM Baubau yang dialihkan menjadi aktivitas CSR selama pandemic covid-19. Dana yang dianggarkan untuk ketiga aktivitas tersebut diperuntukkan untuk pengadaan sejumlah bantuan baik sembako, alat kesehatan, sarana kebersihan, maupun bantuan sosial lainnya dalam pencegahan dan penanggulangan covid-19 di Kota Baubau.

Selain pengadaan bantuan dari dana CSR yang diinisiasi langsung, Pertamina TBBM Baubau juga berkoordinasi dengan Pemerintah Daerah Kota Baubau dalam hal ini Satgas Covid-19 Kota Baubau terkait kebutuhan mendesak yang diperlukan dalam penvegahan dan penanggulangan covid-19. Dengan demikian, Pertamina TBBM Baubau berhasil bersinergi dengan Pemerintah Daerah Kota Baubau dalam meminimalisasi penularan Covid-19 melalui alokasi dana CSR tahun 2020.

Sesuai dengan komitmennya dalam kegiatan CSR, Pertamina TBBM Baubau juga turut mendukung perekonomian masyarakat di lingkungan perusahaan selama pandemic covid-19. Dukungan tersebut dalam bentuk pembelian masker kain 1000 pcs yang diproduksi oleh ibu-ibu rumah tangga di Kelurahan Sulaa dan nantinya masker kain tersebut diserahkan ke satgas Covid-19 Baubau untuk disalu rkan kepada tenaga medis dan masyarakat.

\subsection{Analisis Semiotika Terhadap Laporan CSR Pertamina TBBM Baubau Selama Pandemi Covid-19}

Laporan keberlanjutan (Sustainability Report) adalah salah satu media yang memiliki tujuan dalam pengungkapan pertanggungjawaban atas keseluruhan social activity yang dilakukan oleh perusahaan. Sustainability report dapat memediasi keberadaan asimetri informasi antara korporasi dengan stakeholder. Laporan CSR juga menjadi tools untuk mengevaluasi kinerja CSR yang dilakukan oleh korporasi. Realitanya, financial reporting perusahaan tidak saja menyajikan informasi kuantitatif, melainkan juga informasi lain seperti teks naratif, image, table,dan chartgrafik yang termuat dalam pelaporan CSR. Upaya memaknai dari setiap kata, symbol, ataupun kalimat pada teks naratif dengan tujuan sebagai penyampaian informasi kepada stakeholder adalah proses retorika (Chariri \& Nugroho, 2009).

Retorika dalam pelaporan CSR Pertamina TBBM Baubau Selama Pandemi Covid-19 dapat dilihat pada laporan divisi HSSE Pertamina TBBM Baubau yang memiliki tugas dan fungsi dalam menjalankan CSR. Selain itu, pelaporan dan pengungkapan CSR dilakukan melalui pemanfaatan media massa baik media online, media cetak maupun media sosial lainnya seperti Instagram yang dimiliki oleh Pertamina TBBM Baubau.

a) Cover Laporan CSR Pertamina TBBM Baubau

Cover pada laporan CSR Pertamina TBBM Baubau bertujuan untuk membangun image/citra positif atas korporasi. Cover tersebut mendeskripsikan dengan tegas seluruh aspek aktivitas CSR selama pandemic covid-19.

b) Kata Pengantar

Bagian ini berisi kata pengantar dari manager Pertamina TBBM Baubau dalam bentuk teks naratif. Manager Pertamina TBBM Baubau menyatakan 
komitmen penuh terhadap going concern. Hal tersebut menjabarkan keseriusan dalam menjalankan selu ruh aktivitas operasinya tanpa mengesampingkan aktivitas tanggung jawab sosial dan lingkungan.

c) Profil Perusahaan

Profil perusahaan dipaparkan secara singkat dalam bentuk teks naratif dan image/gambar aktivitas. Paparan singkat tersebut memuat sejarah berdirinya perusahaan dan review operasional TBBM, sedangkan gambar-gambar menjelaskan rangkaian aktivitas operasional yang dilaksanakan terutama aktivitas terkait tanggung jawab sosial dan lingkungan.

d) Corporate Governance

Bagian ini memaparkan informasi-informasi tentang corporate policy, governance, sistem manajemen dan informasi lainnya terkait dengan stakeholders. Pertamina TBBM Baubau berupaya maksimal dalam memberikan pelayanan yang optimal bagi semua stakeholders. Retorika dalam laporan ini adalah rangkaian proses yang dibangun oleh manajemen Pertamina TBBM Baubau dalam mengajak stakeholder guna mendukung eksistensi korporasi.

e) Pengungkapan dan Pelaporan CSR

Pernyataan manager Pertamina TBBM Baubau dalam laporan CSR adalah bentuk retorika yang dipilih dalam penyampaian message kepada stakeholders yang berdampak pada legitimasi perusahaan. Setiap aktivitas CSR ditulis dalam uraian kalimat yang jelas, singkat dan bahasa yang mudah dipahami disertai bukti image/gambar sehingga mampu memberi keyakinan para stakeholders dalam memahami apa yang diungkapkan dalam laporan tersebut.

\subsection{Pemberitaan Media Massa Terkait Aktivitas CSR Pertamina TBBM Baubau Selama Pandemi Covid-19}

Media massa memiliki peran penting sebagai sumber penyampaian informasi atas bermacam fenomena baik yang telah terjadi maupun sedang berlangsung di lingkungan masyarakat, dan diharuskan untuk memberitakan perihal tersebut sesuai dengan kondisi sesungguhnya. Oleh karena itu, pembuktian kesahihan retorika pada aktivitas CSR Pertamina TBBM Baubau selama pandemic covid-19, peneliti menghimpun bermacam pemberitaan di media massa online tentang aktivitas CSR Pertamina TBBM Baubau selama pandemic covid-19. Adapun beberapa pemberitaan tersebut yaitu:

\subsubsection{Berita Kota Online (diberitakan pada tanggal 19 September 2020)}

Berita Kota Online mengungkapkan bahwa dalam upaya peningkatan kesadaran pola perilaku masyarakat di tengah masa pandemi dan implementasi adaptasi new normal, PT. Pertamina Persero Marketing Operation Region (MOR) VII membentuk desa siaga Covid-19 di berbagai daerah, salah satunya berada di Kota Baubau, tepatnya di Kelurahan Lipu. Pernyataan Unit manager Comm. Rel \& CSR, Laode S Mursali yang dijabarkan dalam berita tersebut, menyebutkan bahwa program ini sebagai wujud responsive Pertamina terhadap pandemi Covid-19: "Pada intinya kita mengedukasi masyarakat, jangan sampai abai dan tidak disiplin menerapkan protocol kesehatan. Karena saat ini, angka positif Covid-19 terus meningkat, ungkapnya, Jumat (18/9)". 


\section{Beritacita Kota}

* Balaikota Lingkar Sultra Akadomika Ekonomika Aktualita Kasuistika Pollika Arona Opini Feature Etalase $Q \equiv$

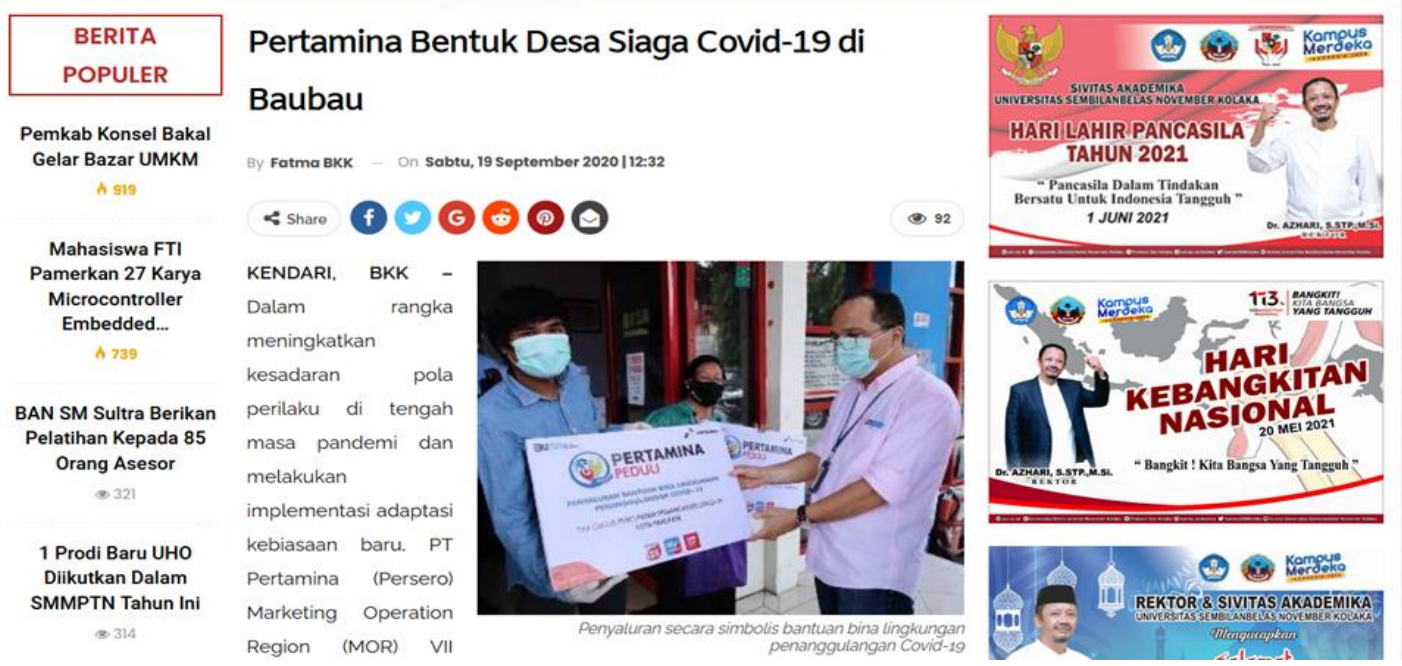

Gambar 1. Penyaluran secara simbolis bantuan bina lingkungan penanggulangan Covid-19 oleh PT. Pertamina (Persero) (Fatma, 2020)

\subsubsection{Rubrik Sultra (diberitakan pada tanggal 09 Oktober 2020)}

Fuel Terminal Bahan Bakar Minyak (TBBM) Baubau menyerahkan bantuan Corporate Social Responsibility (CSR) PT Pertamina (Persero) ke Gugus Tugas Covid-19 Baubau. Bantuan itu diterima langsung Sekretaris Gugus Tugas, Dr Ro n i Muhtar, Kamis 8 Oktober 2020. Bantuan berupa sembako sebanyak 350 paket, wastafel sebanyak 5 unit, masker kain 1000 pcs, faceshield 200 pcs, galon cuci tangan kecil 10 unit, handsanitizer 25 liter dan sabun cuci tangan 10 botol masing masing $500 \mathrm{ml}$. Adi Rachman mengatakan bahwa: "Diharapkan kesediaan Gugus Tugas Covid19 Baubau dapat menerima bantuan CSR ini lalu disalurkan kepada masyarakat sehingga dapat bermanfaat khususnya dalam rangka menanggu lan $\mathrm{i}$ Covid-19 di Kota Baubau" (Admin Rubrik Sultra, 2020)

\subsubsection{Buton Raya News diberitakan pada tanggal 14 Oktober 2020)}

Sekretaris Daerah (Setda) Kota Baubau Dr. Roni Muchtar, M.Pd., menyampaikan apresiasi dan ucapan terima kasih kepada PT. Pertamina (Persero) Marketing Operation Regional VII Fuel Terminal Baubau atas peran aktifnya dalam upaya penanggulangan Covid-19. Hal tersebut ia sampaikan saat menerima secara simbolis sejumlah bantuan untuk masyarakat Baubau terdampak Covid-19 yang di serahkan langsung oleh Fuel Terminal Manager Baubau Adi Rachman di Sekber Covid-19 pekan kedua bulan oktober 2020.

"PT. Pertamina (Persero) Fuel Teriman Baubau merupakan contoh perusahaan yang baik. Pasalnya. PT. Pertamina (Persero) telah secara terus menerus memanfaatkan dana CSR untuk memperdayakan masyarakat guna meningkatkan perekonomian. Selain itu, pihaknya juga tengah merancang Peraturan Daerah (Perda) tentang Community Development" (Redaksi, 2020). 


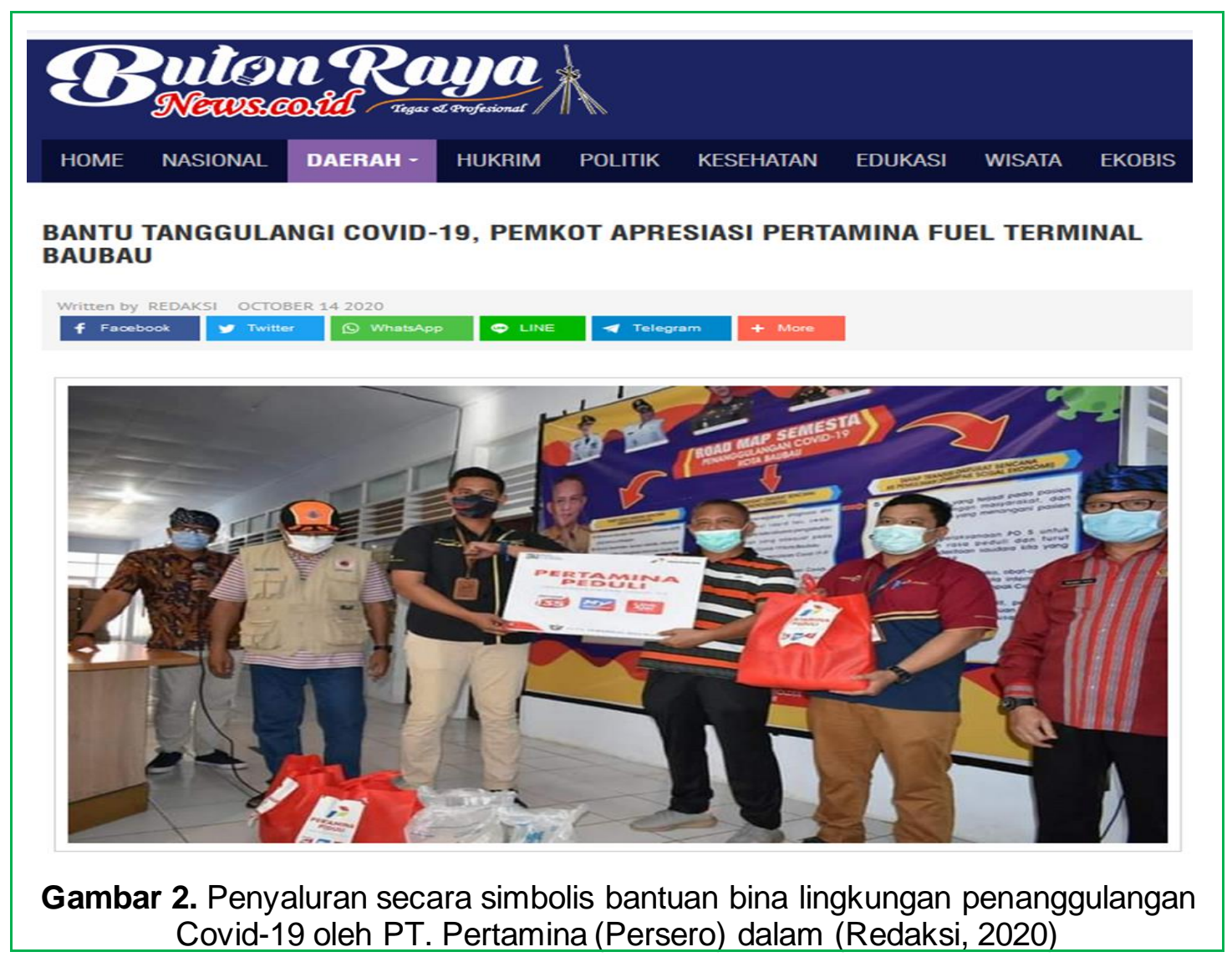

Dari beberapa pemberitaan yang dijabarkan diatas terkait aktivitas CSR Pertamina TBBM Baubau selama pandemic covid-19, menunjukkan bahwa pengungkapan aktivitas CSR pada tahun 2020 bersifat keterbukaan. Pemberitaan positif mengenai aktivitas social and environment Pertamina TBBM Baubau. Oleh karena itu, tujuan pengungkapan CSR secara jujur dan terbuka dapat dicapai oleh entitas melalui pemanfaatan media massa.

\section{Pembahasan}

Implementasi CSR adalah bagian tak terpisahkan dari pola pengimplementasian etika bisnis bagi korporasi. Orientasi CSR bukan hanya pada profit tetapi turut memberi perhatian terhadap masyarakat dan lingkungan sekitar (Oktanti, 2015). Pelaporan dan pengungkapan CSR dalam sustainability reporting bertujuan untuk menjembatani information asymetrhy antara perusahaan dengan stakeholders. Pertamina TBBM Baubau dibawah naungan Marketing Operation Region (MOR) VII Sulawesi PT Pertamina (Persero) memiliki kewajiban untuk melaporkan aktivitas CSR yang dilakukan kepada MOR VII Sulawesi dalam bentuk laporan divisi HSSE Pertamina TBBM Baubau.

Laporan CSR Pertamina TBBM Baubau disusun dalam bentuk teks naratif melalui penegasan image/gambar, table dan grafik yang merupakan bagian dari cerita retorik yang dapat dianalisis melalui analisis semiotik. Selaras dengan tujuan penelitian yang ingin dicapai dalam penelitian ini, hasil analisis semiotik terhadap laporan CSR yang disusun oleh divisi HSSE Pertamina TBBM Baubau menunjukkan bahwa penggunaan kalimat yang jelas, singkat dan pemaknaan bahasa yang mudah dimengerti serta simbol-simbol yang digunakan memberi keyakinan dan nilai positif terhadap stakeholders akan terlaksananya aktivitas CSR 
Pertamina TBBM Baubau khususnya selama pandemic covid-19. Selain pengungkapan yang diinisiasi sendiri oleh Pertamina TBBM Baubau, media massa baik online maupun cetak turut memberitakan secara positif seluruh aktivitas CSR yang dilakukan bahkan memperoleh apresiasi dari pemerintah daerah. Pertamina TBBM Baubau menjadi salah satu contoh terbaik bagi BUMN yang mengalihkan dana CSR yang dimiliki pada kegiatan pencegahan dan penanggulangan Covid19.

Penelitian yang mengusung topik retorika dalam sustainability reporting juga dilakukan oleh (Chariri \& Nugroho, 2009); (Priyanti, Kamayanti, \& Atmadja, 2011); dan (Oktanti, 2015). Ketiga riset tersebut menegaskan bahwa cerita retorik dalam sustainability reporting menjadi sumber keyakinan stakeholders dan turut mebentuk positive image bagi perusahaan. Hal ini disebabkan oleh narasi yang digunakan dalam pelaporan seluruh aktivitas CSR adalah eufemisme (penghalusan bahasa) dan metafora. Pengungkapan CSR juga terbukti berdampak pada peningkatan reputasi sehingga memperbaiki korelasi terhadap stakeholders, dan hasil perbaikan tersebut tercermin pada laba ekonomi perusahaan (Jo \& Harjoto, 2011).

\section{Kesimpulan}

Berdasarkan analisis semiotik yang dilakukan dalam penelitian ini, kesimpulan yang dapat dijabarkan adalah pelaporan dan pengungkapan CSR baik melalui laporan divisi, laporan perusahaan maupun pemanfaatan media teknologi merupakan pola implementasi etika bisnis dan corporate governance yang baik. Dengan adanya pelaporan dan pengungkapan tersebut akan berdampak pada positive image dari seluruh pemangku kepentingan terhadap perusahaan. Selain itu, berdasarkan analisis semiotik pada laporan divisi HSSE Pertamina TBBM Baubau atas aktivitas CSR selama pandemic covid-19 yang berupa teks naratif, baik yang berbentuk paragraf penjelas dan gambar adalah bentuk persuasive yang dapat memengaruhi argumentasi stakeholder atas penilaian kinerja CSR. Pertanggungjawaban sosial Pertamina TBBM Baubau dilaksanakan dengan baik, yakni melalui pembuktian gambar aktivitas dan alokasi realisasi dana CSR selama pandemic covid-19. Hal ini juga didukung dengan pemberitaan positif oleh beberapa media massa online baik lokal maupun wilayah. Tentunya, harapan stakeholder terhadap kegiatan CSR BUMN menjadi pola pemberdayaan dan peningkatan perekonomian masyarakat yang berkesinambungan.

\section{Daftar Pustaka}

Admin Rubrik Sultra. (2020). Fuel TBBM Baubau Serahkan Bantuan CSR ke Gugus Tugas Covid-19. Retrieved June 30, 2021, from Rubrik Sultra website: https://rubriksultra.com/fuel-tbbm-baubau-serahkan-bantuan-csr-ke-gugustugas-covid-19/

Anis Chariri. (2008). The Dynamics of Financial Reporting Practice in an Indonesian Company: A Reflection of Javanese Views on an Ethical Social Relationship. (July 2008).

Basalamah, A. S., \& Jermias, J. (2005). Social and Environmental Reporting and Auditing in Indonesia: Maintaining Organizational Legitimacy? Gadjah Mada International Journal of https://doi.org/10.22146/gamaijb.5565 
Chariri, A., \& Nugroho, F. A. (2009). Retorika Dalam Pelaporan Corporate Social Responsibility: Analisis Semiotikatas Sustainability Reporting Pt Aneka Tambang Tbk. (1996), 1-24.

Fatma, B. (2020). Pertamina bnetuk Desa Siaga Covid-19 di Baubau. Berita Kota Kendari. Retrieved from https://beritakotakendari.com/2020/09/pertaminabentuk-desa-siaga-covid-19-di-baubau/

Hines, R. D. (1988). Financial accounting: In communicating reality, we construct reality. Accounting, Organizations and Society, 13(3), 251-261. https://doi.org/10.1016/0361-3682(88)90003-7

Hoed, B. H. (2011). Benny H. Hoed,. 13(2), 386-389.

Jo, H., \& Harjoto, M. A. (2011). Corporate Governance and Firm Value: The Impact of Corporate Social Responsibility. Journal of Business Ethics, 103(3), 351383. https://doi.org/10.1007/s10551-011-0869-y

Narsa, I. M., \& Irwanto, A. (2014). Implementasi Tanggung Jawab Sosial PT Petrokimia Gresik pada Masyarakat Lokal: Apa Kata Mereka? Jurnal Akuntansi Multiparadigma, 5(3). https://doi.org/10.18202/jamal.2014.12.5034

Oktanti, A. D. (2015). Retorika Pengungkapan CSR Melalui Analisis Semiotik pada Perusahaan Pemenang ISRA 2013 (PT. Kaltim Prima Coal). Jurnal IImiah Mahasiswa FEB Universitas Brawijaya, 3(2).

Pertiwi, I. D. A. E., \& Ludigdo, U. (2013). Implementasi Corporate Social Responsibility. Jurnal Akuntansi Multiparadigma, 4(3), 330-507. https://doi.org/http://dx.doi.org/10.18202/jamal.2013.12.7208

Priyanti, E., Kamayanti, A., \& Atmadja, S. S. (2011). Mengeksplorasi Kepedulian Lingkungan dan Sosial PT. AKR Corporindo TBk. Melalui Laporan CSR (Stu di Semiotika dan Indeks Pengungkapan). Jurnal Media Mahardika, 9(2).

Redaksi. (2020). Bantu Tanggulangi Covid-19, Pemkot Apresiasi Pertamina Fuel Terminal Baubau. Retrieved June 30, 2021, from Buton Raya News website: http://butonrayanews.co.id/index.php/daerah/buton -raya/bau-bau/item/2663bantu-tanggulangi-covid-19-pemkot-apresiasi-pertamina-fuel-terminal-baubau 